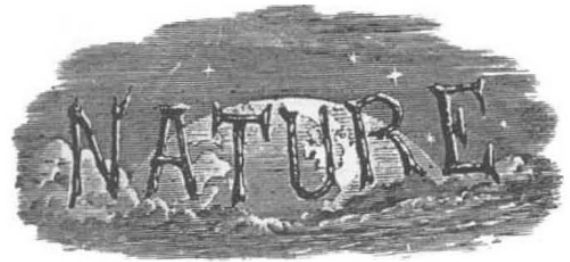

SATURDAY, JANUARY I7, I93I.

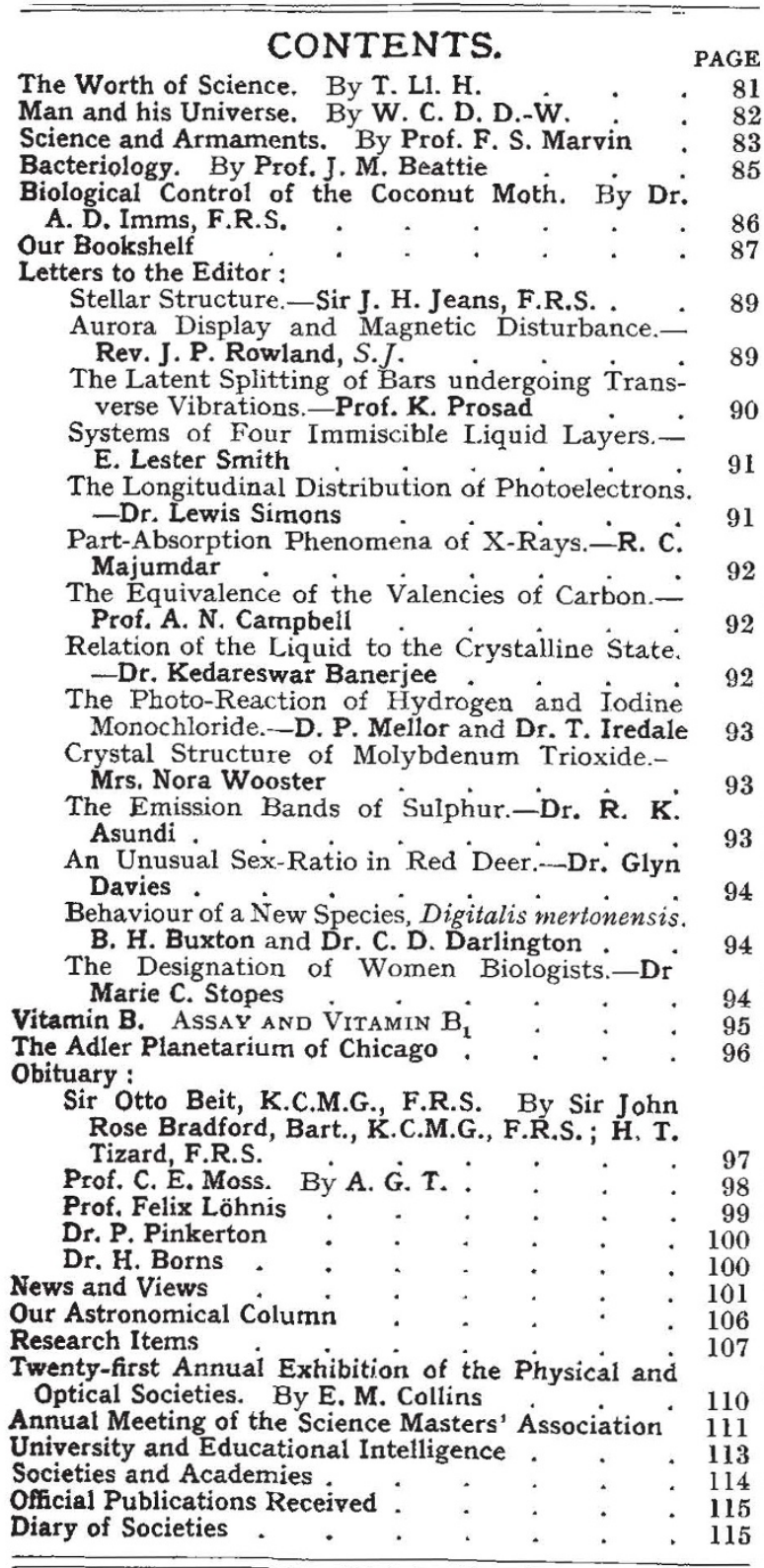

Editorial and Publishing Offres:

MACMILLAN \& CO., LTD.,

ST. MARTIN'S STREET, LONDON, W.C.2.

Telephone Number: GERRARD 8830.

Telegraphic Address: PHUSIS, WESTRAND, LONDON.

No. 3194, Vor. 127]

\section{The Worth of Science.}

$\mathrm{A}_{\mathrm{T}}^{\mathrm{T}}$ the nineteenth annual Conference of EducaA tional Associations, held at University College, London, the president, Sir Richard Gregory, selected as the subject of his inaugural address "The Worth of Science". The address was no mere catalogue raisonné of the contributions of science to material progress and human comfort, no mere addition of the economic value of scientific discoveries. In terms of billion and bullion only, no such evaluation is possible; for the liberation of life and intellect brought about by the work of the pioneers of scientific discovery is beyond price. Galileo's classic words, Eppur.si muove, helped to establish man's right "to think for himself in the realm of natural knowledge and to place personal observation above metaphysical and philosophical speculation and dogmatic assertion ". Teachers may well be reminded of this debt to science, for without this spirit of freedom, "bequeathed from bleeding sire to son ", their work would be degraded and the punishment reserved for them by Lucian, to sell kippers in the lower world, would be well deserved.

Science has suffered some hard buffetings, especially in the United States, because the doctrine of evolution is supposed to be concerned with the obvious resemblances between men and monkeys and to envisage human progress in terms of "Nature, red in tooth and claw". But, as Sir Richard Gregory pointed out, evolution embodies the idea of social ethics, making the welfare of the community the essential purpose of the life of the individual. If we study Nature we shall find abundant examples of ruthless cruelty, "void and empty of every drachm of mercy", but we shall also find most beautiful examples of patience, co-operation, selfsacrifice, and other virtues of which the human race cannot claim the patent.

Finally, if it is fair to attempt such rapid summary of this admirable address, Sir Richard impressed the great lesson that science must not be blamed for the use to which its riches, its cornucopia, its bulging corn-bins, are applied by the human race. For more than a century chlorine had served a useful purpose as a disinfectant and a bleaching agent, before its use in warfare provided one of the greatest tragedies of the War. If science offers to mankind a new earth, the question whether the new earth is better than the old depends on human will, on human judgment. Science enables us to speak by wireless across the estranging ocean, but when the ethereal link is joined, have we anything 
worth saying? Thomas Love Peacock remarks that civilised man admits he is unhappy anywhere and then congratulates himself on devising a machine which will transport him rapidly from one place where he is unhappy to another where he is not less unhappy.

The wheel of life takes a full turn and, like the alarum clock which awakes us to another day's labour, science awakes us at intervals to a new world. Galileo escaped with the comfortable punishment of being immured in his own study; but some of his contemporaries might have gone to the stake for the simple proposition that the earth goes round the sun. After some centuries of intense study and research, the universe is still mysterious, more mysterious than to Galileo and his inquisitors; and if Einstein, Eddington, or Jeans were asked the simple question, "Does the earth go round the sun?" the answer, we suppose, would not be a plain yes or no. Whatever that answer may be, however incomprehensible the mathematics used for its demonstration, there would be no auto-da-fé, no question of martyrdom. Eppur si muove-though the modern world is able on occasion to devise subtle forms of persecution for the man of science.

The impossibility of reaching finality is part of the lure of science, and, in a sense, of the "Worth of Science". Turning to medicine, Sir Richard Gregory said, with perhaps a soupçon of superiority, "When a savage is ill, he naturally attributes his sufferings to some enemy within him, and to witchcraft putting the enemy there ". As regards certain diseases, that is apparently also the present view. Dr. H. P. Newsholme in his essay on certain aspects of encephalitis lethargica, entitled "Health, Disease, and Integration", attributes this disease in man to a lack of balance "within him ". Owing possibly to some evil thought or memory, to some repression, the body cells begin to behave in a peculiar way. Encephalitis lethargica has secured a new victim. We must not exclude the possibility of learning from the untutored savage, though he may not have the hebdomadal privilege of reading Nature. The wise men of the east have wrested secrets from the book of Nature by the simple method of doing nothing, secrets which Homo sapiens of the west would not have discovered by fevered activity.

Who shall point the way to the birthplace of Christ? Sir Richard Gregory did not evade this aspect of his subject. He properly reminded us of Lessing's dilemma, the choice between truth and the impulse towards truth. Leave the reality of absolute truth to its Creator and accept the impulse towards truth as the guide of life, and we shall be as happy as George Meredith's costermonger's donkey, going blithely along at a trot, merry in harness while we have to serve. Happy-and humble too. Is it not one of the greatest assets in the balance-sheet of science that it teaches those lessons of true humility which helped and comforted Bunyan's pilgrim on his weary progress? -

He that is humble ever shall

Have God to be his guide.

T. LL. H

\section{Man and his Universe.}

Man and his Universe. By John Langdon-Davies. Pp. xviii $+334+14$ plates. (London: Harper and Bros., 1930.) 16s, net.

TTHE author of this book has set forth in non1 technical language a series of pictures of man and the universe as seen by our primitive ancestors, by men of the Middle Ages, and by those who lived during the Renaissance, the Darwinian epoch, at the end of the nineteenth century, and finally in 1930 . We may say at once that, when reconciled to the occasionally journalistic style, the reader can study the book with profit and interest. We may criticise points of historical detail and feel unconvinced by some of the lessons the author draws from modern science, but we must admit that on the whole the work is well done, and that at all events it makes a good story.

Mr. Langdon-Davies's main position is that science from one aspect is poetry (concealed by text-books) and from another a search for God, in the course of which a series of new gods are discovered. To explain the influence of science on religion, Mr. Langdon-Davies quotes W. K. Clifford : "The character of the emotion with which men contemplate the world, the temper in which they stand in the presence of the immensities and the eternities, must depend first of all on what they think the world is".

Mr. Langdon-Davies is quite right in holding that, to understand our present outlook on life, we must know something not only of savage superstitions and modern science, but something also of the thought of the intervening two thousand years. He overlooks the earliest part of this time - the age of the pre-Aristotelian Greek philosophers, and also that of the first Christian synthesis of knowledge, which was predominantly Platonic and Augustinian. He assumes that the influence of Aristotle was supreme throughout the 